\title{
SELEKCJA, BRAKOWANIE I POCZĄTKI NADZORU NAD NIMI W GALICJI DO WYBUCHU PIERWSZEJ WOJNY ŚWIATOWEJ
}

\section{UWAGI WSTĘPNE}

(Calicja była tą częścią podzielonej przez zaborców Rzeczypospolitej, w któUI rej archiwa-instytucje zostały utworzone najpóźniej. Wynikało to z ogólnej sytuacji dziedziny archiwalnej w monarchii austro-węgierskiej, gdzie aż do początku lat sześćdziesiątych XIX w. - poza centralnymi archiwami wiedeńskimi - nie było archiwów historycznych. Także gdy zaczęto je tworzyć, stanowiły one instytucje finansowane przez autonomiczne władze krajowe, co nie do końca sprzyjało gromadzeniu przez nie wszystkich archiwaliów, szczególnie proweniencji państwowej ${ }^{1}$. Pierwsze archiwum krajowe zostało utworzone w 1862 r. w Pradze. W 1863 r. powołano archiwum krajowe w Wiedniu, a w kolejnych latach powstały podobne palcówki w Grazu, Kla-

${ }^{1}$ Jeszcze w końcu XIX w. lwowska biblioteka uniwersytecka, próbując uzasadnić gromadzenie archiwaliów sądowych i skarbowych z terytorium Galicji Wschodniej, twierdziła, że we Lwowie nie ma archiwum państwowego mogącego gromadzić materiały proweniencji urzędowej, dlatego to przez nią mogą być one zabezpieczone, zob. Centralne Historyczne Archiwum Państwowe Ukrainy we Lwowie (dalej: CHAPU), Archiwum Państwowe we Lwowie 1832-1939 (dalej: AP we Lwowie), f. 776, op. 1, sygn. 51, k. 21v i 23. 
genfurcie, Brnie, Opawie i Innsbrucku². W Galicji już wiosną 1869 r. władze centralne zaproponowały przekazanie Wydziałowi Krajowemu akt grodzkich i ziemskich przechowywanych przy sądach wyższych w Krakowie i Lwowie ${ }^{3}$. Ostatecznie dopiero w sierpniu 1877 r. Sejm Krajowy zaakceptował wnioski Wydziału o przejęcie obu archiwów. Dzięki temu w Krakowie i Lwowie zostały utworzone Archiwa Krajowe Aktów Grodzkich i Ziemskich.

Powodem, dla którego zaproponowano galicyjskiemu Wydziałowi Krajowemu przejęcie ksiąg wytworzonych przez sądy dawnej Rzeczypospolitej, była utrata przez tę dokumentację praktycznego znaczenia dla administracji sądowej Austro-Węgier ${ }^{4}$. Przechowywanie ksiąg sądowych zbytnio obciążało budżet centralny, a i same sądy borykały się nieustannie z brakiem miejsca na materiały powstające w wyniku własnej działalności. Według szacunków już na początku XIX w. każdy z galicyjskich sądów wytwarzał przeciętnie nawet kilka metrów sześciennych akt rocznie'.

W tym artykule zostały zawarte przede wszystkim informacje o mechanizmach selekcji i brakowania akt w galicyjskich sądach w ciągu XIX i na początku XX w. ${ }^{6} \mathrm{~W}$ dalszej kolejności scharakteryzowano początki opieki nad archiwaliami, sprawowanej aż do pierwszych lat XX w. przez różne kręgi zainteresowanych. Poza tym znalazły się tu odpowiedzi na dwa pytania: kto od początku XX w. miał odpowiadać za nadzór nad selekcją i brakowaniem akt przez aktotwórców oraz w jaki sposób te działania były prowadzone?

Problematyka selekcji i brakowania akt w urzędach galicyjskich była już prezentowana w polskiej literaturze archiwistycznej. Bardzo dużo uwagi poświęcił jej Ludwik Łysiak, pisząc w połowie XX w. dwa artykuły dotyczące registratur, odpowiednio sądu krajowego karnego w Krakowie oraz sądu szlacheckiego w Tarnowie 7 . O działalności zachodniogalicyjskiego Grona Konserwatorów w 1976 r. pisała Jadwiga Szyposz ${ }^{8}$, a na początku XXI w. prace

2 S. Ciara, Archiwa a uniwersytety $w$ Krakowie i Lwowie w latach 1877/78-1918, Warszawa 2002, s. 13-14.

3 S. Sochaniewicz, Archiwum krajowe aktów grodzkich i ziemskich we Lwowie, Przewodnik Naukowy i Literacki, R. 40, 1912, s. 1025.

4 Tamże.

5 L. Łysiak, Registratura sądu krajowego karnego w Krakowie i jej brakowanie, Archeion, t. 22, 1954, s. 169-170.

6 W zasadzie tylko one wykazywały w tym zakresie jakąkolwiek aktywność.

7 L. Łysiak, Registratura sądu krajowego karnego w Krakowie i jej brakowanie, s. 156-195; tenże, Sąd szlachecki w Tarnowie. Studium archiwalne z dziejów kancelarii i registratury sądów w Galicji, Archeion, t. 24, 1955, s. 305-328.

8 J. Szyposz, Dziatalność Grona Konserwatorów Galicji Zachodniej w zakresie zabezpieczania archiwaliów, Archeion, t. 64, 1976, s. 59-80. 
jego lwowskiego odpowiednika scharakteryzował Stefan Ciara w ramach obszernej rozprawy poświęconej związkom archiwów z uniwersytetami w Krakowie i we Lwowie9 . Ostatnio próbował on także omówić doświadczenia archiwistów galicyjskich na przełomie XIX i XX w. w zakresie postępowania $\mathrm{z}$ dokumentacją masową ${ }^{10}$.

Materiałami źródłowymi wykorzystanymi w artykule są przepisy publikowane w dziennikach urzędowych wychodzących w Austro-Węgrzech, dostępne obecnie on-line $\mathrm{w}$ internetowym serwisie „ALEX” na stronie austriackiej biblioteki narodowej ${ }^{11}$. Oprócz nich wykorzystano mające charakter źródłowy informacje umieszczane w wydawnictwach firmowanych przez galicyjskich konserwatorów ${ }^{12}$ oraz bardzo ważny z punktu widzenia przedmiotu artykułu zbiór listów Oswalda Balzera i Stanisława Kutrzeby, opracowany i opublikowany w „Krakowskim Roczniku Archiwalnym” przez Ewę Perłakowską ${ }^{13}$. Nie zapomniano także o materiałach archiwalnych z zasobów Archiwum Państwowego w Krakowie oraz Centralnego Historycznego Archiwum Państwowego Ukrainy we Lwowie, szczególnie tych, które zostały wytworzone przez krakowskie i lwowskie $\operatorname{archiwa}^{14}$.

9 S. Ciara, dz. cyt., s. 31-41.

10 Tej tematyce zostało poświęcone wystąpienie S. Ciary w czasie konferencji zorganizowanej 25 i 26 XI 2010 r. w Poznaniu, której przedmiotem była właśnie dokumentacja masowa, problemy jej wartościowania i selekcji. Zob. zamieszczone w tym tomie „Archiwów - Kancelarii - Zbiorów” sprawozdanie z tego sympozjum napisane przez Martę Pawłowską i Katarzynę Pepłowską.

11 Tu przede wszystkim „Dziennik Ustaw Państwa dla Królestw i Krajów w Radzie Państwa Reprezentowanych” oraz „Verordnungsblatt des K. K. Justizministeriums”, zob. http://alex.onb.ac.at [dostęp 12 grudnia 2011 r.].

12 Chodzi tu najpierw o „Tekę Konserwatorską. Rocznik Koła c.k. Konserwatorów Starożytnych Pomników Galicyi Wschodniej”, potem „Sprawozdania Koła CK Konserwatorów i Korespondentów Galicji Wschodniej” (dalej: SKckKiK) oraz „Tekę Grona Konserwatorów Galicji Zachodniej” (dalej: TGKGZ).

13 Listy Oswalda Balzera i Stanistawa Kutrzeby z 1907 roku w sprawie brakowania akt sądowych, oprac. E. Perłakowska, Krakowski Rocznik Archiwalny, t. 7, 2001, s. 167-175.

${ }_{14}$ Archiwum Państwowe w Krakowie (dalej: APK), Archiwum Państwowe w Krakowie [1818] 1951-1962 (dalej: AP w Krakowie); CHAPU, Archiwum Ziemskie we Lwowie 1784-1939 (dalej: AZ we Lwowie), f. 145; tamże, AP we Lwowie, f. 776. 


\section{SELEKCJA I BRAKOWANIE AKT PRZEZ AKTOTWÓRCów}

Brak archiwów historycznych w Galicji nie przeszkadzał instytucjom we własnym zakresie zarządzać selekcję i przeprowadzać brakowanie akt. Regulacje dotyczące wydzielenia dokumentacji do zniszczenia pojawiały się w Cesarstwie Austriackim już na początku XIX w. Ich autorami były lokalne władze państwowe, które poszukując miejsca dla wytwarzanych na bieżąco akt, doraźnie zlecały usunięcie starych papierów z registratur własnych i podległych im urzędów. Przykładem może być Prezydium Gubernium galicyjskiego - w tym czasie wydało ono takie zarządzenia trzykrotnie: 28 listopada 1808 r., 4 stycznia 1809 r. i 16 lipca 1827 r. ${ }^{15} \mathrm{~W}$ tym ostatnim przypadku nakazano poddać ocenie akta wytworzone w latach 1772-1820. Wykonaniem zadania mieli zająć się urzędnicy odpowiadający za prowadzenie registratury. Polecono im zniszczyć całą pochodzącą z tego okresu dokumentację, chyba że dotyczyła ona spraw zainicjowanych przed końcem 1820 r. i załatwianych w latach następnych.

Można przypuszczać, że nakreślony wyżej mechanizm selekcji był typowy dla większości urzędów funkcjonujących w pierwszym ćwierćwieczu XIX stulecia w monarchii habsburskiej. To stwierdzenie dotyczy zarówno procedury wydzielania akt do zniszczenia, jak i wykorzystywanego w selekcji kryterium, które wiązało wartość zachowywanej dokumentacji z jej urzędową przydatnością. Pewną zmianę przyniosło wydanie 8 marca 1832 r. przez Franciszka I pierwszej regulacji dotyczącej brakowania akt we wszystkich urzędach państwa. Informujący o niej dekret cesarskiej kancelarii nadwornej z 24 marca nakazywał usuwać z registratur akta bezużyteczne, natomiast zachować te, które „noch notwendig oder nützlich oder wichtig sein wird, oder es werden könnten, und auch solche, welche obwohl zum ämtlichen gebrauche nicht mehr dienlich, doch in historischer oder sonstiger Beziehung einigen Wert haben oder haben dürften" ${ }^{\prime 6}$.

Pierwszą istotną różnicą między wcześniejszą praktyką regulowaną lokalnymi przepisami a zasadami zapisanymi w dekrecie z $1832 \mathrm{r}$. było uzupełnienie stosowanego kryterium selekcji o wartość historyczną dokumentacji.

15 Zob. odpis okólnika z 16 VII 1827 r. zachowany w aktach Urzędu Wojewódzkiego Krakowskiego, APK, Urząd Wojewódzki Krakowski [1892] 1921-1939 (dalej: UWK), sygn. 4, k. 1205; w treści tego okólnika są przywołane podane wyżej zarządzenia z 1808 i 1809 r.

16 Odpis dekretu zob. APK, UWK, sygn. 4, k. 1204. 
Ta cecha akt oraz ich dotychczas uznawana przydatność do celów urzędowych stały się czynnikami uzasadniającymi wykluczanie części dokumentacji z brakowania. Poza tym przepisy z początku lat trzydziestych XIX w. niewiele zmieniły w procedurze wydzielania i niszczenia dokumentacji. Mimo że nakazywały wyłączenie z brakowania akt charakteryzujących się wartością historyczną, nie mówiły o konieczności ich wieczystego zabezpieczenia. Nadal selekcja i brakowanie akt w urzędach monarchii habsburskiej były działaniami doraźnymi, mającymi na celu opróżnienie w konkretnym momencie registratur urzędowych z nadmiaru dokumentacji. Nic nie stało na przeszkodzie, aby akta wyłączone z jednego brakowania zostały przeznaczone do zniszczenia w czasie następnego.

Przepisy regulujące selekcję i brakowanie akt w urzędach monarchii habsburskiej wydawane w latach późniejszych przyjęły sformułowane w 1832 r. kryterium. Wyjątkową aktywność w zakresie brakowania dokumentacji przejawiało do końca XIX w. c.k. Ministerstwo Sprawiedliwości ${ }^{17}$. Pierwsze rozporządzenie nakazujące wydzielić do zniszczenia niepotrzebne akta sądów apelacyjnych, kryminalnych, magistratów większych miast orzekających w sprawach karnych, sądów kolegialnych i magistratów orzekających w sprawach cywilnych, uwzględniające zasady wprowadzone w 1832 r., zostało wydane 16 października 1843 r. ${ }^{18}$ Sześć lat później, w związku z reorganizacją sądownictwa, 24 października 1849 r., zarządzono niszczenie dokumentacji, która miała nie być przydatna administracji funkcjonującej na podstawie nowych przepisów. W dniu 15 lipca 1876 r. zostało wydane rozporządzenie ministra sprawiedliwości regulujące selekcję i brakowanie akt spraw karnych, 24 października 1896 r. ukazało się kolejne, tym razem odnoszące się do wszystkich rodzajów akt spraw.

Przepisy wydawane przez resort sprawiedliwości w ciągu XIX w. początkowo dokładniej opisywały grupę akt uznawanych za niezbędne do działalności urzędowej. W 1843 r. należały do niej rejestry i akta normatywne, materiały dotyczące organizacji urzędu, jego personelu, sprawozdania z działalności oraz oryginalne dokumenty złożone przez strony w czasie postępowań przed sądem ${ }^{19}$. W 1896 r. lista rodzajów tej dokumentacji była jeszcze

${ }^{17}$ Była to konsekwencja rosnącej stale produkcji aktowej w sądach monarchii, zob. przyp. 5.

${ }_{18}$ To rozporządzenie, jak i pozostałe przepisy c.k. Ministerstwa Sprawiedliwości przywołane w tym akapicie zob. L. Łysiak, Registratura sqdu krajowego karnego w Krakowie i jej brakowanie, s. 170-175.

19 Tamże, s. 170. 


\section{Robert Degen}

dłuższa i bardziej precyzyjna ${ }^{20}$. Oprócz już wymienionych, ze względu na przydatność urzędową miały być zachowane akta spraw procesów karnych zagrożonych karą śmierci, protokoły podawcze wraz z indeksami, księgi registratury, rejestry główne trybunałów i sądów powiatowych, indeksy osobowe i rejestry ukaranych. W przypadku dokumentacji spraw karnych prowadzonych według przepisów z początku XIX w. nakazywano zachowywać wnioski z końcowym załatwieniem wraz z wyrokami wszystkich instancji i dowodami wykonania kary. Dla dokumentacji spraw karnych procedowanych na podstawie przepisów z lat późniejszych polecano zachowywać wyroki z motywami, protokoły rozprawy głównej, tabele wywiadowcze, dowody wykonania kary (jeśli karę zasądzono) lub uchwały zawierające końcowe załatwienie wraz z aktami potrzebnymi do ich zrozumienia (jeśli sprawa została załatwiona w inny sposób). Do tego wyłączone z brakowania miały być akta dotyczące spraw rachunkowych i zarządu depozytu sądowego.

Akta należące do grupy zachowanej ze względu na wartość historyczną były opisywane w dziewiętnastowiecznych przepisach c.k. Ministerstwa Sprawiedliwości mniej dokładnie. Zarządzenie z 1843 r. nie egzemplifikowało rodzajów tej dokumentacji i powoływało się jedynie na ogólną zasadę zachowania akt użytecznych ze względów historycznych czy naukowych. W 1896 r. za warte zachowania z tego powodu uznano już - nieco precyzyjniej - akta wszystkich spraw sądowych wytworzone do 1800 r. oraz akta spraw karnych prowadzonych na zasadach obowiązujących do wprowadzenia ustawy karnej w 1803 r.

Procedura selekcji i brakowania akt przewidziana przepisami resortu sprawiedliwości z XIX w. zmieniała się nieznacznie ${ }^{21}$. Zawsze - do 1896 r. - dokumentacja była wydzielana do zniszczenia przez pracowników konkretnych sądów (zatrudnionych w ich registraturach, ewentualnie kancelariach, przy współudziale urzędników z komórek organizacyjnych, których dokumentację poddawano selekcji). Aby ułatwić im pracę, od 1843 r. zaczęto w zarządzeniach określać czas, po którym akta należące do różnych grup mogą zostać zniszczone. I tak właśnie na początku lat czterdziestych XIX w. po 10 latach można było zniszczyć m.in. terminarze procesowe i księgi ekspedycji, a po 30 - dzienniki podawcze i ich rejestry. Ostateczną decyzję o tym, czy dokumentację wydzieloną do zniszczenia rzeczywiście zlikwidować, podejmowali sami

20 Tę listę Łysiak podał na podstawie zestawienia opracowanego przez c.k. Sąd Krajowy Wyższy w Krakowie, obejmującego wskazówki ujęte wcześniej w przepisach z 1843, 1849, 1876 i 1896 r., zob. tamże, s. 175.

21 Tamże, s. 171-179. 
aktotwórcy. W 1843 r. nadzór nad wydzielaniem dokumentacji miały sprawować prezydia sądów. Ich zadaniem było powołanie doraźnych komisji brakowania dokumentacji, kontrolujących prace urzędników wyodrębniających akta, udzielających wskazówek i rozstrzygających wątpliwości co do okresu ich przechowywania. W 1849 r. całkowita odpowiedzialność za zniszczenie akt niepotrzebnych została zrzucona na urzędników powoływanych do brakowania akt przez szefów sądów. Po wejściu w życie przepisów z 1876 r. ostateczna decyzja o zniszczeniu akt zależała od prezydiów sądów krajowych wyższych.

\section{POCZĄTKI OPIEKI NAD ARCHIWALIAMI}

Wszystkie przywołane wyżej przepisy dotyczące selekcji i brakowania akt były opracowywane bez udziału archiwistów lub uczonych zainteresowanych wykorzystaniem archiwaliów do celów naukowych. Nie oznacza to, że w połowie XIX w. nie podejmowano nad Dunajem działań prowadzących do zabezpieczenia akt mających wartość historyczną. Już wówczas rozproszone na prowincji archiwalia przechowywane przez parafie, gminy miejskie, ale także materiały uznane przez sądy za warte zachowania $\mathrm{z}$ historycznego punktu widzenia znalazły się w orbicie zainteresowań służby konserwatorskiej monarchii, władz poszczególnych królestw i krajów oraz lokalnych instytucji naukowych.

Zaczątkiem austro-węgierskiej służby ochrony zabytków była Centralna Komisja do Badania i Zachowywania Zabytków Architektury (k.k. Central-Commission zur Erforschung und Erhaltung der Baudenkmale), utworzona w Wiedniu w końcu grudnia 1850 r. ${ }^{22}$ W lipcu 1873 r. otrzymała ona nowy statut i zaczęła działać jako c.k. Centralna Komisja do Badania i Zachowywania Zabytków Sztuki i Pomników Historycznych (k.k. Central-Commission zur Erforschung und Erhaltung der Kunst- und Historischen Denkmale) ${ }^{23}$.

22 Tekst programowy określający cel i metody działania komisji zob.: R. v. Eiltelberger, Die Aufgabe der Althertumskunde in Österreich, Mittheilungen der K. K. Central-Commission zur Erforschung und Erhaltung der Baudenkmale, R. 1, 1855, nr 1, s. 1-4; wersja elektroniczna na stronie http://www.archive.org/stream/mittheilungender01kkze\#page/n11/mode/2up [dostęp 12 grudnia 2011 r.].

23 Rozporzadzenie ministerstwa wyznań i oświecenia z dnia 21 lipca 1873, tyczace się nowego statutu dla komisji centralnej badania $i$ zachowywania zabytków sztuki i pomników historycznych i sam statut zob. „Dziennik Ustaw Państwa dla Królestw i Krajów w Radzie Państwa Reprezentowanych”, 1873, nr 48, poz. 131, s. 561-563; wersja elektroniczna na stronie http://alex.onb.ac.at [dostęp 12 grudnia 2011 r.]. 
Była organem podległym c.k. Ministerstwu Wyznań i Oświecenia ${ }^{24}$. Swoim nadzorem obejmowała wszystkie zabytki przeszłości, także archiwalia. Jej zadania zostały sformułowane bardzo ogólnie. Komisja miała pobudzać do badania i zachowywania „zabytków sztuki i pamiątek przeszłości”, zabezpieczać je przed zniszczeniem, zachęcać i wspierać tego rodzaju działalność prowadzoną przez uczonych i lokalne towarzystwa naukowe, wreszcie popularyzować wiedzę na temat rezultatów swojej pracy. Początkowo jedynymi przedstawicielami komisji w terenie byli pełniący swe obowiązki społecznie konserwatorzy zabytków historycznych. Powoływano ich dla określonych terytoriów, o ile to możliwe - osobno dla zabytków archeologicznych, architektonicznych i sztuki oraz archiwaliów. W miarę upływu czasu komisja zaczęła korzystać z pomocy korespondentów, wspierających wysiłki konserwatorów. Statut komisji nie przewidywał pośrednich form organizacyjnych skupiających lokalnych konserwatorów i korespondentów, niemniej w Galicji zawiązały się w 1888 r. krakowskie Grono c.k. Konserwatorów Galicji Zachodniej $^{25}$ i lwowskie Koło (od 1905 r. także Grono) c.k. Konserwatorów i Korespondentów Galicji Wschodniej ${ }^{26}$. W lwowskim kole już od początku działała sekcja archiwalna ${ }^{27}$, w Krakowie jej odpowiednik ukonstytuował się w 1908 r. ${ }^{28}$ Dla celów urzędowych organizacje konserwatorskie dzieliły znajdujące się w strefie ich zainteresowania terytorium na okręgi konserwatorskie. W zachodniej części Galicji do 1907 r. istniały dwa okręgi, potem ich liczbę zwiększono do czterech ${ }^{29}$. Galicja Wschodnia do 1906 r. stanowiła jeden okręg konserwatorski, później wydzielono w niej drugi ${ }^{30}$.

24 Zob. Statut dla komisyi centralnej do badania i zachowywania zabytków sztuki i pomników historycznych, „Dziennik Ustaw Państwa dla Królestw i Krajów w Radzie Państwa Reprezentowanych”, 1873, nr 48, poz. 131, s. 561-563; wersja elektroniczna na stronie http://alex.onb.ac.at [dostęp 12 grudnia 2011 r.].

$25 \mathrm{O}$ działalności archiwalnej członków zachodniogalicyjskiego grona zob. J. Szyposz, dz. cyt., s. 59-80.

26 Pełniejszą charakterystykę działalności wschodniogalicyjskich konserwatorów zob. S. Ciara, dz. cyt., s. 31-41.

27 Kronika czynności Kota c.k. Konserwatorów i Korespondentów Galicyi Wschodniej, Teka Konserwatorska. Rocznik Koła c.k. Konserwatorów Starożytnych Pomników Galicyi Wschodniej, 1892, s. 149.

28 Z protokotów posiedzeń Grona, TGKGZ, t. 3, 1909, s. 302.

29 Mimo że liczba okręgów do 1907 r. nie zmieniała się, ich granice nie były stałe. Reorganizację podziału do celów konserwatorskich przeprowadzono w 1894 r., zob. J. Szyposz, dz. cyt., s. 60-62.

30 S. Ciara, dz. cyt., s. 32-33. Początkowo archiwa znajdujące się we wschodniej części Galicji stanowiącej jeden okręg konserwatorski były podzielone na dwie grupy: 
Do końca XIX w. członkowie zrzeszeń konserwatorskich wykonywali swoje obowiązki dzięki podejmowanym niezbyt regularnie podróżom, których cel stanowiło przede wszystkim zbieranie informacji o archiwaliach. Co prawda, już w 1868 r. Beda Dudik opublikował pierwszy opis archiwów galicyjskich $^{31}$, lecz potrzeba dalszych działań w tym zakresie, powiązanych z zabezpieczeniem akt, była aż nadto odczuwalna wśród krakowskich i lwowskich uczonych. W 1880 r. podczas I zjazdu historyków polskich Michał Bobrzyński postulował, aby obecni na spotkaniu uczeni uchwalili z jednej strony konieczność poddania kontroli wszystkich galicyjskich archiwów lokalnych, z drugiej zaś uznali za rzecz niezbędną zbieranie dokładnych informacji na temat wszystkich lokalnych archiwów ${ }^{32}$. Zachodniogalicyjscy konserwatorzy i korespondenci archiwalni do 1897 r. odwiedzili m.in. archiwa Jarosławia, Nowego i Starego Sącza, Przemyśla, Rzeszowa czy Tarnowa ${ }^{33}$. W czasie wypraw oprócz odnajdywania archiwaliów rozproszonych na prowincji - o ile to było możliwe - porządkowali je i inwentaryzowali. Zdarzało się im także wyszukiwać nowe pomieszczenia dla odnalezionych archiwów ${ }^{34}$. Lwowscy konserwatorzy od początku lat dziewięćdziesiątych XIX w. przyczynili się m.in. do przejęcia przez bibliotekę uniwersytecką dwóch prywatnych zbiorów rękopiśmiennych - Hieronima Sadowskiego z Czortkowa i Ludwika Zielińskiego, podjęli wysiłki mające na celu zabezpieczenie odnalezionych w Potyliczu

archiwa ruskie (cerkiewne i klasztorne) i pozostałe archiwa, którymi zajmowali się osobni konserwatorzy. Wydzielając w 1906 r. dodatkowy okręg, utworzono go z myślą o ułatwieniu opieki nad archiwami innymi niż ruskie.

${ }^{31}$ B. Dudik, Archive im Königreiche Galizien und Lodomerien, Archiv für Österreichische Geschichte, t. 39, 1868, s. 1-222. Po B. Dudiku opisy archiwów galicyjskich wyszły spod pióra m.in. Waleriana Hecka, zob.: W. Heck, Archiwum miejskie w Wadowicach, Wadowice 1889; tenże, Archiwa miejskie księstw Oświęcimskiego i Zatorskiego, Kraków 1891, czy Antoniego Serafińskiego. Napisany przez ostatniego z wymienionych inwentarz akt miejskich został przesłany krakowskiemu gronu konserwatorskiemu, zob. APK, Grono Konserwatorów Galicji Zachodniej 1847-1923 (dalej: GKGZ), sygn. 9, s. 262.

32 Pamiętnik pierwszego zjazdu historycznego polskiego imienia Jana Dtugosza odbytego $w$ Krakowie w czterechsetna rocznice jego śmierci, wyd. M. Bobrzyński, M. Sokołowski, Kraków 1881, s. 43.

33 J. Szyposz, dz. cyt., s. 65; sprawozdania z podróży konserwatorów zob. APK, GKGZ, sygn. 39, s. 191-459.

${ }^{4}$ Taki zakres zadań podali S. Krzyżanowski i S. Estreicher w sprawozdaniu z podróży odbytej latem 1896 r.: „Podczas naszej podróży wypadło nam nieraz starać się o lepsze pomieszczenie archiwaliów, dokonywać ich katalogowania, porządkowania lub zabezpieczania od zniszczeń. Zwłaszcza obchodzenie się z dokumentami pergaminowymi pozostawiało szczególnie wiele do życzeń”, zob. APK, GKGZ, sygn. 39, s. 195. 


\section{Robert Degen}

ksiąg miejskich potylickich i grodzkich bełskich z początku XVI w. ${ }^{35}$, uczestniczyli w rozwiązaniu sporu między gminą Dolina domagającą się zwrotu archiwaliów miejskich od byłego pisarza miejskiego Stanisława Lewickiego, interweniowali w sprawie zabezpieczenia przeciwpożarowego archiwum miejskiego w Przemyślu ${ }^{36}$.

W końcu lat osiemdziesiątych w działania prowadzące do zabezpieczenia archiwaliów włączyły się władze autonomii ${ }^{37}$. W 1887 r. Sejm Galicyjski nakazał Wydziałowi Krajowemu zbadać możliwości przejęcia akt gminnych przez archiwa krajowe lub stworzenia mechanizmu kontroli zabezpieczonej przez miasta dokumentacji. Wówczas także Wydział rozesłał do wszystkich miast galicyjskich (z wyjątkiem Krakowa i Lwowa) okólnik, w którym polecił gminom odpowiednio dbać o archiwa, sporządzić inwentarze ksiąg i aktów będących w ich posiadaniu, wreszcie - jeśli nie będą mogły tym wymaganiom sprostać - przekazać archiwalia jednemu z archiwów krajowych. Do 1900 r. 74 miasta oddały swoją dokumentację w depozyt archiwów w Krakowie i Lwowie.

Mimo że archiwa krajowe wydawały się najlepszym miejscem dla zabezpieczenia archiwaliów, nie tylko one w latach dziewięćdziesiątych XIX w. zaangażowały się w gromadzenie dawnych akt. Najlepszym przykładem jest lwowska biblioteka uniwersytecka, która już w latach 1890-1891 włączała do swoich zbiorów archiwalia proweniencji prywatnej ${ }^{38}$. Wiosną $1894 \mathrm{r}$. biblioteka poprosiła Prezydium c.k. Sądu Krajowego Wyższego we Lwowie o przekazywanie jej „cennych starodawnych akt” zgromadzonych przez sądy działające na prowincji ${ }^{39}$. Prezydium wydało stosowny okólnik i w ten sposób w bibliotece znalazły się akta z sądów powiatowych w Kołomyi, Lubaczowie, Skale, Śniatyniu i Żółkwi ${ }^{40}$. Rok później biblioteka zwróciła się z podobną prośbą do Prezydium c.k. Krajowej Dyrekcji Skarbu, a w konsekwencji jej zbiory zasiliły materiały wybrane z registratur samej dyrekcji krajowej, c.k. Powiato-

${ }^{35}$ Kronika czynności Kota c.k. Konserwatorów i Korespondentów Galicyi Wschodniej, s. 153.

36 S. Ciara, dz. cyt., s. 35-36.

37 A. Winiarz, Co uczyniono dotąd w Galicji dla ratowania archiwaliów gmin miejskich i wiejskich i co jeszcze do zrobienia pozostaje, [w:] Pamiętnik III zjazdu historyków polskich w Krakowie urzadzonego przez Towarzystwo Historyczne Lwowskie w dniach 4, 5 i 6 czerwca 1900, t. 1: Referaty, Kraków 1900, s. nlb.

38 Zob. wyżej w tekście.

39 Zob. przyp. 1.

40 CHAPU, AP we Lwowie, f. 776, op. 1, sygn. 50, k. 15-28. 
wej Dyrekcji Skarbu, c.k. Prokuratorii Skarbu i c.k. Urzędu Ceł ${ }^{41}$. W 1899 r. - powołując się na decyzje władz sądowych i skarbowych z lat 1894-1895 biblioteka sama domagała się już od ich terenowych organów przekazywania cennych $\mathrm{akt}^{42}$. Jej zaangażowanie może tłumaczyć fakt, że w tym czasie było z nią związanych zawodowo trzech członków lwowskiego grona konserwatorskiego $^{43}$.

\section{KTO KONTROLOWAE SELEKCJĘ I BRAKOWANIE AKT PRZEZ AKTOTWÓRCÓW?}

W odniesieniu do końca XIX w. można mówić o świadomych działaniach zmierzających w Austro-Węgrzech do wskazania i zabezpieczenia akt ważnych z historycznych względów. Należy jednak pamiętać, że te działania prowadziło wiele ośrodków, a funkcjonujące już wówczas archiwa krajowe nie były wśród nich instytucjami najważniejszymi. Zmianę tego stanu mogły przynieść podjęte na początku lat dziewięćdziesiątych XIX w. starania mające na celu pełne uporządkowanie spraw archiwalnych monarchii habsburskiej. Zainicjowano je już w latach sześćdziesiątych XIX w., jednak dopiero na początku lat dziewięćdziesiątych XIX w. nabrały one tempa i przyniosły pierwsze rezultaty. Projekt reformy dziedziny archiwalnej został przedstawiony na posiedzeniu Izby Panów Rady Państwa w marcu 1893 r. Celem zaproponowanych zmian było zorganizowanie w Austro-Węgrzech archiwów zgodnie z wymogami, jakie stawiała przed nimi nowoczesna nauka. Projekt mówił m.in. o konieczności zatrudniania w archiwach pracowników mających odpowiednie przygotowanie merytoryczne oraz odpowiedniego finansowania służby archiwalnej. Oprócz tego odnosił się do brakowania akt przez aktotwórców. Według założeń projektu ta czynność miała podlegać kontroli wspomnianej wcześniej c.k. Centralnej Komisji do Badania i Zachowywania Zabytków Sztuki i Pomników Historycznych ${ }^{44}$.

Efektem debaty dotyczącej spraw archiwalnych było powołanie jesienią 1894 r. Rady Archiwalnej, która miała współpracować z c.k. Ministerstwem Spraw Wewnętrznych w kwestiach odnoszących się do archiwów. W pierwszym roku działalności celem Rady stało się przede wszystkim okre-

41 Tamże, k. 30r-30v; CHAPU, AP we Lwowie, f. 776, op. 1, sygn. 51, k. 34-36.

42 CHAPU, AP we Lwowie, f. 776, op. 1, sygn. 51, k. 1-2.

43 Zob. przyp. 57.

44 S. Ciara, dz. cyt., s. 15; zob. też A. Winiarz, Archiwum namiestnictwa we Lwowie, Lwów 1909, s. 3-4. 
ślenie kwalifikacji zawodowych urzędników archiwalnych oraz ustalenie zasad opracowania archiwaliów w archiwach podległych MSW. Później zajęła się sprawami selekcji i brakowania. Inaczej niż w założeniach reformy, Radzie nie udało się sformułować ogólnych zasad oceny wartości archiwaliów i wprowadzić powszechnej kontroli nad brakowaniem akt przez aktotwórców. W związku z kolejną planowaną przez resort sprawiedliwości akcją niszczenia akt sądowych Rada skoncentrowała się na selekcji i brakowaniu materiałów tej proweniencji. W jej gronie został utworzony specjalny podkomitet. Projekt wytycznych dotyczących brakowania materiałów sądowych został przedstawiony Radzie Archiwalnej na posiedzeniu 15 lutego 1897 r., a ostateczna ich wersja została przyjęta w marcu $1897 \mathrm{r}^{45}$

Wytyczne dotyczące selekcji i brakowania akt przez administrację sądową wprowadziły zakaz niszczenia jakichkolwiek akt wytworzonych do $1815 \mathrm{r}$. oraz uszczegółowiły kryteria selekcji w porównaniu do wcześniej stosowanych rozwiązań. Ze względu na wartość historyczną zachęcano do zachowywania akt procesów w sprawach politycznych, ważniejszych procesów prasowych, konfiskat publikacji i zakazów rozpowszechniania książek. Podobnie wyłączone z brakowania miały być akta ruchów społecznych, ważne źródła do dziejów Kościoła i religii, materiały biograficzne dotyczące polityków i twórców, dokumentacja istotna dla historii ekonomicznej oraz akta powstałe w okresach wyjątkowo burzliwych w dziejach poszczególnych regionów, także odnoszące się do sytuacji na konkretnym terytorium tuż po przyłączeniu go do monarchii habsburskiej. Wówczas zaproponowano też listę archiwów, którym sądy miały przekazywać warte zachowania akta po przeprowadzeniu brakowania ${ }^{46}$.

Zalecenia Rady Archiwalnej w zakresie brakowania akt znalazły odbicie w przepisach o brakowaniu akt wydawanych przez c.k. Ministerstwo Sprawiedliwości. Już 1 lutego 1897 r. wydało ono reskrypt, w którym nakazano sądom specjalną ostrożność przy wydzielaniu do zniszczenia akt wytworzonych przed $1847 \mathrm{r}$. oraz zalecano zbadanie ich przed zniszczeniem przez pracownika archiwum historycznego lub konserwatora zabytków ${ }^{47}$. Podobnie wydana 5 maja 1897 r. instrukcja dla sądów I i II instancji umożliwiała zwró-

${ }^{45}$ S. Ciara, dz. cyt., s. 16-18.

46 Tamże.

${ }^{47}$ L. Łysiak, Registratura sadu krajowego karnego w Krakowie i jej brakowanie, s. 182, przyp. 2; do tego zarządzenia dostosowało się Prezydium Sądu Krajowego Wyższego w Krakowie, które 24 II 1897 r. wydało podległym mu sądom zarządzenie, realizujące zalecenia z reskryptu ministerialnego z 1 lutego, zob. L. Łysiak, Sąd szlachecki $w$ Tarnowie, s. 323. 
cenie się o ekspertyzę do właściwego archiwum historycznego lub innej instytucji naukowej ${ }^{48}$. Wreszcie rozporządzenie c.k. Ministerstwa Sprawiedliwości z 28 października 1897 r. nakazywało wszystkim sądom zawiadamiać właściwe archiwa (w zależności od kraju - prowadzone przez namiestnika lub rząd krajowy) o każdorazowym wydzielaniu akt do zniszczenia ${ }^{49}$.

Rozwiązania wypracowane przez Radę Archiwalną w końcu XIX w. i wdrożone w austro-węgierskich sądach tylko w minimalnym zakresie zostały przyjęte przez inne działy administracji. Do 1917 r. jedynie ${ }^{50}$ c.k. Ministerstwo Skarbu poszło w ślady resortu sprawiedliwości i latem 1901 r. wydało zarządzenie regulujące zasady brakowania akt w prokuratoriach skarbowych ${ }^{51}$. Podobnie jak sądy, także te instytucje zostały zobowiązane do poinformowania właściwych archiwów państwowych przed zniszczeniem niepotrzebnych materiałów. Konieczność uzyskania zgody organów zewnętrznych na brakowanie dokumentacji dostrzegały też władze lokalne. Już na początku XX w. Wydział Krajowy we Lwowie i tamtejsze Namiestnictwo, niezależnie od siebie, kilkakrotnie przypominały o tym starostom ${ }^{52}$. Inaczej niż administracja sądowa, Wydział i Namiestnictwo wskazywały na konserwatorów sztuki jako

48 Tak należy rozumieć zapis z $\$ 299$ : „O ile nie zapadnie postanowienie, że wydzielone akta mają być oddane do archiwum namiestnictwa lub rządu krajowego lub innego archiwum wyznaczonego przez Ministerstwo sprawiedliwości, celem fachowego zbadania przez organa archiwalne, albo że taka rewizya jakim innym sposobem ma być uskutecznioną, należy wydzielone akta sprzedać", zob. Rozporządzenie Ministra Sprawiedliwości z dnia 5 maja 1897, którem zostaje wydana instrukcja dla sąów pierwszej i drugiej instancji, „Dziennik Ustaw Państwa dla Królestw i Krajów w Radzie Państwa Reprezentowanych", 1897, nr 41, poz. 112, s. 706; wersja elektroniczna na stronie http://alex.onb. ac.at [dostęp 12 grudnia 2011 r.].

49 Verordnung des Justizministeriums vom 28. Oktober 1897, Z. 18932 betreffend die Ueberprüfung ausgeschiedener Acten durch Archive, Verordnungsblatt des K. K. Justizministeriums, 1897, nr 22, poz. 34, s. 363-364; wersja elektroniczna na stronie http://alex. onb.ac.at [dostęp 12 grudnia 2011 r.].

${ }^{50} \mathrm{Na}$ to, że tylko władze sądowe i częściowo administracja skarbowa mają w Austro-Węgrzech uregulowane kwestie brakowania akt i nadzoru nad nim, zwracał uwagę w swoim memoriale z 1917 r., skierowanym do Rady Archiwalnej, dyrektor archiwum w Innsbrucku Michael Mayr, zob. L. Łysiak, Registratura sqdu krajowego karnego i jej brakowanie, s. 186-187.

${ }^{51}$ Odpis Verordnung des Finanzministeriums bettrefend die Ausscheidung und Vernichtung entbechricher Acten bei den Finanzprocuraturen z 14 VII 1901 r. zob. APK, AP w Krakowie, sygn. 45, s. 475-483.

52 Sprawozdania Grona c.k. Konserwatorów i Korespondentów Galicyi Wschodniej (dalej: SGckKiK), nr 52-63, 1907, s. 2; tamże, nr 64-75, 1908, s. 2; tamże, nr 76$-87,1909$, s. 7. 
odpowiedzialnych za zabytki przeszłości. Domagały się, aby byli oni informowani o wszystkich wydawanych przez starostów zarządzeniach dotyczących akt, również tych mówiących o planowanej selekcji i brakowaniu akt.

Przedstawione powyżej rozważania przekonują, że w Galicji na początku $\mathrm{XX}$ w. funkcjonowały dwa ośrodki, które mogły kontrolować proces selekcji i brakowania akt przeznaczonych do zniszczenia przez aktotwórców. Były to archiwa krajowe i organizacje konserwatorskie. Trudno stwierdzić, czy istniała między nimi hierarchiczna zależność. Okólniki wydawane przez władze prowincji ogólnie wskazywały na konserwatorów jako odpowiedzialnych za dawne dokumenty, a część członków gron zajmujących się opieką nad archiwaliami była równocześnie pracownikami galicyjskich archiwów. Spośród ośmiu konserwatorów i korespondentów archiwalnych w Gronie c.k. Konserwatorów Galicji Zachodniej od połowy lat dziewięćdziesiątych XIX w. ${ }^{53}$ tylko Stanisław Estreicher, Fryderyk Papée ${ }^{54}$ i Bronisław Ulanowski - jakkolwiek znakomici znawcy archiwów i zbiorów rękopiśmiennych - nie pracowali w krakowskich archiwach. W kole, a później w gronie lwowskim, sytuacja wyglądała inaczej. Oprócz Ksawerego Liskego (był konserwatorem i kierował

53 Liczba podana na podstawie informacji z artykułu Jadwigi Szyposz, zob. J. Szyposz, dz. cyt., s. 60-61, 64. Oprócz wymienionych wyżej Estreichera, Papée i Ulanowskiego, od 1894 r. sprawami archiwalnymi jako członkowie krakowskiego grona zajmowali się: Franciszek Piekosiński (archiwariusz miejski w Krakowie w latach 1887-1889, dyrektor archiwum krajowego w latach 1892-1906, zob. A. Kiełbicka, Piekosiński Franciszek Ksawery (1844-1906), [w:] Stownik biograficzny archiwistów polskich (dalej: SBAP), t. 2, red. B. Woszczyński, Warszawa 2002, s. 137-139), Stanisław Krzyżanowski (od 1890 r. związany z Archiwum Aktów Dawnych m. Krakowa, zob. A. Kiełbicka, Krzyżanowski Stanistaw (1865-1917), [w:] SBAP, t. 2, s. 98-99), Stanisław Kutrzeba (w latach 1901-1908 pracownik archiwum krajowego w Krakowie, w latach 1906-1908 p.o. jego dyrektora, zob. A. Kiełbicka, Kutrzeba Stanistaw Marian (1876-1946), [w:] SBAP, t. 2, s. 103-105), Adam Chmiel (pracownik archiwum miejskiego w Krakowie od 1890 r., zob. Biogramy uczonych polskich. Materiaty o życiu i dziatalności cztonków AU w Krakowie, TNW, PAU i PAN, cz. 1: Nauki spoteczne, z. 1: A-J, oprac. A. Śródka, P. Szczawiński, Wrocław i in. 1983, s. 199) i Kazimierz Kaczmarczyk (podobnie jak Chmiel, związany od początku XX w. z Archiwum Aktów Dawnych m. Krakowa, zob. I. Radtke, Kaczmarczyk Kazimierz (1878-1966), [w:] SBAP, t. 1, red. M. Bielińska, I. Janosz-Biskupowa, Warszawa-Łódź 1988, s. 93).

54 Trzeba jednak pamiętać, że Papée w 1879 r. w wiedeńskim Institut für österreichische Geschichtsforschung zdał egzamin uprawniający do wykonywania m.in. zawodu archiwisty, jednak życie zawodowe związał z bibliotekami naukowymi - najpierw Ossolineum, później bibliotekami uniwersyteckimi we Lwowie i Krakowie, W. Bieńkowski, Papée Fryderyk (1856-1940), [w:] Polski stownik biograficzny, t. 25, Wrocław-Warszawa-Kraków-Gdańsk 1980, s. 161-162. 
w tym samym czasie Archiwum Krajowym Aktów Grodzkich i Ziemskich, lecz zmarł w 1891 r., czyli przed wprowadzeniem w życie przepisów dla sądów z 1897 r.) i Aleksandra Czołowskiego ${ }^{55}$, pozostali konserwatorzy i korespondenci archiwalni działający na terytorium Galicji Wschodniej byli związani bądź z uniwersytetem ${ }^{56}$, bądź z lwowskimi bibliotekami naukowymi ${ }^{57}$. Także Eugeniusz Barwiński, od 1913 r. szef Archiwum Państwowego we Lwowie, w czasie pełnienia obowiązków konserwatorskich w latach 1906-1910 pracował w bibliotece uniwersyteckiej ${ }^{8}$.

Jest bardziej prawdopodobne, że organizacyjna zależność między stowarzyszeniami konserwatorskimi a archiwami nie istniała. Jeszcze w 1907 r. Oswald Balzer traktował konserwatorów jako siłę niezależną, realizującą własne zadania w zakresie ochrony zabytków kultury rękopiśmiennej i raczej nie do wykorzystania w czasie rewizji archiwaliów sądowych ${ }^{59}$. Można wskazywać na pewne związki natury merytorycznej, w których zrzeszenia konserwatorów zajmowały wyższą pozycję, co sugeruje sytuacja z jesieni 1907 r., kiedy Stanisław Kutrzeba pełniący obowiązki dyrektora archiwum krajowego w Krakowie (równocześnie konserwator archiwalny) uznał za konieczne zwrócenie się do c.k. Grona Konserwatorów Galicji Zachodniej z prośbą „o zasadnicze orzeczenie, jakie akta [sądowe] należy zachowywać”, by w pełni przestrzegać przepisów z 27 października 1897 r. $^{60}$

55 Od 1891 r. na stanowisku archiwariusza miejskiego we Lwowie, zob. Czołowski-Sas Aleksander (1865-1944), [w:] SBAP, t. 1, s. 47.

56 Zob. S. Ciara, dz. cyt., s. 31-33. Izydor Szaraniewicz (historyk, do 1892 r. zajmował Katedrę Historii Austriackiej), Aleksander Kolessa (wykładał filologię i literaturę ukraińską), Władysław Abraham (specjalista w zakresie prawa kościelnego i polskiego).

57 Zob. tamże. Wojciech Kętrzyński był dyrektorem Zakładu Narodowego im. Ossolińskich, Piotr Skobielski pracował w lwowskiej bibliotece uniwersyteckiej (był jednym ze współwydawców dyplomów archiwum książąt Lubartowiczów Sanguszków ze Sławuty), podobnie Fryderyk Papée (w latach 1883-1905, później przeniósł się do Krakowa, zob. przyp. 54) i Józef Korzeniowski (od 1896 r., S. Konarski, Korzeniowski Józef (1863-1921), [w:] SBAP, t. 1, s. 108). Do żadnej z wymienionych grup nie można przypisać ks. prałata Antoniego Petrusewicza, kustosza kapituły greckokatolickiej we Lwowie.

58 A. Kamiński, Barwiński Eugeniusz (1874-1947), [w:] SBAP, t. 1, s. 34-35.

59 Rozważając sposoby badania akt przed zniszczeniem ich przez sądy, w liście do S. Kutrzeby napisał: „Wątpię, żeby tu [przy przeglądaniu dokumentacji do brakowania] członkowie kół konserwatorskich wiele mogli pomóc, bo i oni nie mogą tyle czasu tym rzeczom poświęcać - i pieniądze wydawać”, zob. Listy Oswalda Balzera i Stanistawa Kutrzeby z 1907 roku, s. 171.

60 Zob. List Stanistawa Kutrzeby do Prezydium c.[esarsko] k.[rólewskiego] Sądu Wyższego w Krakowie, [w:] Listy Oswalda Balzera i Stanistawa Kutrzeby z 1907 roku, s. 173-174. 
Uregulowania kwestii odpowiedzialności za nadzór nad selekcją i brakowaniem akt w Austro-Węgrzech nie przyniosły kolejne zmiany w funkcjonowaniu systemu opieki nad zabytkami ${ }^{61}$. Wiosną 1912 r. zaczęła działać zreorganizowana Rada Archiwalna, która miała zastąpić c.k. Centralną Komisję do Badania i Zachowywania Zabytków Sztuki i Pomników Historycznych w opiece nad archiwaliami. Jej zadaniem miało być między innymi wspieranie instytucji rządowych w sprawach archiwalnych i objęcie opieką archiwaliów posiadanych przez instytucje i osoby prywatne. Reprezentantami Rady w krajach koronnych mieli być konserwatorzy i korespondenci ${ }^{62}$. Do nich należało sprawdzanie stanu uporządkowania archiwów, przygotowania zawodowego archiwistów, informowanie o znalezionych rękopisach archiwalnych i bibliotecznych czy grożących im niebezpieczeństwach. Były to więc te same zadania, które wcześniej wykonywali konserwatorzy i korespondenci centralnej komisji do badania i zachowywania zabytków.

Jeżeli możemy mówić o wyodrębnieniu się archiwów jako ośrodków odpowiadających za kontrolę selekcji i brakowania akt w Galicji w drugim dziesięcioleciu XX w., to tylko dlatego, że zdecydowana większość instytucji planujących wówczas zniszczenie dokumentacji była sądami. Od 1897 r. musiały one informować o brakowaniu dokumentacji właściwe archiwa, a nie inne ośrodki, nawet te, których zadanie stanowiła opieka nad archiwaliami.

W czasie gdy archiwa krajowe zbierały informacje o planowanych przez sądy brakowaniach akt i podejmowały decyzje o tym, które materiały włączyć do swoich zasobów, członkowie organizacji konserwatorskich działali podobnie jak przed 1897 r. Na wschodzie, w 1898 r., Aleksander Czołowski zabrał ze składu makulatury w Fujnie pod Źółkwią kilka tysięcy sztuk akt z XVII-XIX w. wytworzonych przez c.k. Sąd Krajowy Wyższy we Lwowie, z któ-

61 O tych zmianach zob. dokładnie S. Ciara, dz. cyt., s. 23-26.

62 Właśnie korespondentów Rada powołała w Galicji. Byli to w nieznacznej większości - 7 spośród 13 - pracownicy archiwów: Eugeniusz Barwiński (od 1913 r. dyrektor Archiwum Państwowego we Lwowie), Antoni Prochaska i Przemysław Dąbkowski (obaj zatrudnieni w lwowskim archiwum krajowym, ten drugi tylko do 1916 r.), Franciszek Jaworski (archiwum miejskie we Lwowie), Franciszek Duda i Abdon Kłodziński (archiwum krajowe w Krakowie), Kazimierz Kaczmarczyk (archiwum miejskie w Krakowie). Oprócz nich korespondentami Rady zostali: Mychajło Hruszewski i Stefan Tomaszewski (profesorowie uniwersytetu we Lwowie), emerytowany profesor Uniwersytetu Jagiellońskiego Władysław Chotkowski, o. Gerard Kowalski z opactwa w Mogile, radca dworu Aleksander Barwiński i nauczyciel gimnazjum w Wadowicach Teofil Klima. Zob. tamże, s. 25-26. 
rych wyodrębnił materiały o wartości historycznej ${ }^{63}$. Rok później odkupił inne wybrakowane akta od handlarza Selelera ${ }^{64}$. W obu przypadkach materiały włączono do zasobu Archiwum Akt Dawnych m. Lwowa. W 1902 r. koło lwowskie zwróciło się z apelem do społeczeństwa o dostarczanie wszelkich możliwych informacji o starych aktach i rozesłało kwestionariusze do właścicieli dóbr i parafii galicyjskich obu obrządków. W tym samym czasie rozpoczęło starania o zabezpieczenie ksiąg Metryki Józefińskiej przechowywanej w gmachu lwowskiej komory celnej oraz katastru gruntowego z 1820 r. W 1903 r. Wojciech Kętrzyński przeprowadził ekspertyzę osiemnastowiecznych dokumentów odnalezionych i przesłanych kołu lwowskiemu przez nauczyciela z Nadwórnej Karola Notza ${ }^{65}$. Rok później wschodniogalicyjscy konserwatorzy podjęli - na wniosek sformułowany po podróży służbowej przez Fryderyka Papeé - nieudaną próbę zabrania z archiwum zarządu dóbr państwowych w Deletynie akt sądowych z XVII i XVIII w. ${ }^{66} \mathrm{~W}$ Galicji Zachodniej w 1902 r., po doniesieniach prasowych o niszczeniu w Niepołomicach archiwum przechowywanego w dyrekcji domen, grono wysłało tam Adama Chmiela, który przy okazji miał zapoznać się ze stanem archiwum niepołomickiej parafii ${ }^{67}$. W 1909 r. z kolei odkupiono od handlarzy makulaturą archiwum dóbr zatorskich i przekazano je do zasobu Archiwum Akt Dawnych m. Krakowa ${ }^{68}$.

\section{JAK NADZOROWANO SELEKCJĘ I BRAKOWANIE?}

Wspomniane wcześniej rozporządzenia c.k. Ministerstwa Sprawiedliwości z 28 października 1897 r. ${ }^{69}$ oraz c.k. Ministerstwa Skarbu z 14 lipca $1901 \mathrm{r}^{70}$ nakazywały sądom i prokuratoriom skarbu informować właściwe archiwa o każdorazowym wydzielaniu akt do zniszczenia. Tylko przepisy dla sądów przybliżały nieco obowiązki aktotwórców i archiwów związane z organizacją rewizji akt przeznaczonych do brakowania. Przede wszystkim poinformowane o brakowaniu archiwa miały przynajmniej sześć tygodni (nie

63 CHAPU, Archiwum Akt Dawnych miasta Lwowa 1794-1939, f. 55, op. 1, sygn. $46, \mathrm{k} .7$.

64 Tamże, k. 9v.

65 SKckKiK, nr 6-7, 1903, s. 4.

66 S. Ciara, dz. cyt., s. 35-39.

67 APK, GKGZ, sygn. 9, s. 405.

68 APK, GKGZ, sygn. 10, s. 181-185.

69 Zob. wyżej w tekście i przyp. 49.

70 Zob. wyżej w tekście i przyp. 51. 


\section{Robert Degen}

więcej jednak niż trzy miesiące) na zapoznanie się z wydzielonymi do zniszczenia materiałami i przejęcie do swojego zasobu tych akt, które ich zdaniem zasługiwały na zachowanie. Pracownicy archiwum mogli dokonać ekspertyzy na miejscu, odwiedzając sądy, lub poprosić o przesłanie wszystkich akt, które według aktotwórców można było już zniszczyć. Wydatki związane z przeprowadzeniem ekspertyzy, także z przesłaniem do archiwum i ewentualnym odesłaniem dokumentacji do sądu, nie mogły obciążać budżetu wymiaru sprawiedliwości. Aby zaoszczędzić archiwom kosztów odsyłania akt - gdyby nie zdecydowały się na włączenie ich do swojego zasobu - rozporządzenie umożliwiało ich zniszczenie przez dowolny sąd mający siedzibę w tym samym mieście co archiwum.

Obydwa działające w Galicji sądy krajowe wyższe wydały zarządzenia polecające podległym sądom wprowadzić przepisy z 1897 r. W Krakowie nastąpiło to 19 lipca 1898 r. $^{71}$, choć trzeba zaznaczyć, że już nieco rok później - 13 grudnia 1899 r. - resort sprawiedliwości zawiesił prawa krakowskiego archiwum krajowego do badania sądowych akt przeznaczonych do zniszczenia $^{72}$. Lwowski okólnik został wydany 16 lutego 1900 r. $^{73}$ Aktywność sądów zmierzająca do brakowania akt nasiliła się po 1905 r. W połowie sierpnia tego roku c.k. Ministerstwo Sprawiedliwości ponownie wezwało wszystkie sądy do wydzielenia makulatury. We Lwowie dotyczący tego okólnik wydano już 20 listopada 1905 r. $^{74}$, w Krakowie dopiero 16 maja 1906 r. ${ }^{75}$ W dniu 22 grudnia 1906 r. resort wydał rozporządzenie o brakowaniu w aktach spraw cywilnych i karnych sądów, w których ta akcja nie została jeszcze przeprowadzona po ogłoszeniu przepisów z $1897 \mathrm{r}^{76}$

W ciągu pierwszych dziesięciu lat obowiązywania przepisów sądowych z 28 października 1897 r. lwowskie archiwum krajowe decydowało się przede

71 L. Łysiak, Registratura sadu krajowego karnego w Krakowie i jej brakowanie, s. 182 , przyp. 2 .

72 Tamże, s. 180, przyp. 2.

73 CHAPU, AZ we Lwowie, f. 145, op. 1, sygn. 114, s. 67. Dnia 30 III 1900 r. zapisy tego okólnika zostały uzupełnione kolejnym - wyszczególniono w nim akta, na których zniszczenie trzeba uzyskać zgodę c.k. Ministerstwa Sprawiedliwości, zob. CHAPU, AP we Lwowie, f. 776, op. 1, sygn. 75, k. 21.

74 CHAPU, AZ we Lwowie, f. 145, op. 1, sygn. 114, s. 63.

75 L. Eysiak, Sad szlachecki w Tarnowie, s. 325 i przyp. 3. Tu zarówno informacja o reskrypcie ministerialnym, jak i o okólniku sądu krakowskiego.

76 Verordnung des Justizministeriums vom 22. Dezember 1906, betreffend die Ausscheidung und Vernichtung entbehrlich gewordener Registratursakten in Zivil-und Strafsachen, Verordnungsblatt des K. K. Justizministeriums, nr 24, 1906, poz. 23, s. 313-314; wersja elektroniczna na stronie http://alex.onb.ac.at [dostęp 12 grudnia 2011 r.]. 
wszystkim poznawać zawartość akt przeznaczonych do zniszczenia za pomocą korespondencji z zainteresowanymi sądami (zwłaszcza obwodowymi) ${ }^{77}$. Kilkakrotnie prosiło je o przesłanie ważniejszych działów dokumentacji. Rzadko - choć była to dla kierującego wówczas archiwum Oswalda Balzera najlepsza metoda przeprowadzenia rewizji $\mathrm{akt}^{78}$ - wykonywano ekspertyzy na miejscu w sądach, z reguły mieszczących się we Lwowie. Tylko raz jeden z aplikantów archiwalnych został posłany na prowincję. Zresztą, o czym przekonywał przykład z działalności archiwum krajowego w Krakowie, nie zawsze ocena wartości akt wydzielonych przez pracowników sądowych była możliwa. Zdarzało się, że praca urzędników sądu powodowała taki chaos w przeznaczonych do zniszczenia aktach, że nawet gdyby archiwum krajowe zechciało coś włączyć do swojego zasobu spośród akt wydzielonych przez sąd, miałoby trudności ze znalezieniem odpowiedniej dokumentacji w stosie makulatury ${ }^{79}$.

Ustaleniem zasad oceny akt proweniencji sądowej zajęło się w 1907 r. na wniosek Kutrzeby zachodniogalicyjskie grono konserwatorów ${ }^{80}$. Opracowane wskazówki nieznacznie regulowały procedurę rewizji dokumentacji, choć określenie grup akt sądowych wartych zachowania nie mogło pozostać bez wpływu na działania archiwów krajowych. Grono zaproponowało, by w całości lub w przeważającej części zabezpieczyć akta spraw cywilnych jednego sądu powiatowego i jednego sądu okręgowego. Spośród dokumentacji spraw karnych w sądach powiatowych zalecało zachowanie wyłącznie akt mających znaczenie kulturalne, wytworzonych w wyniku procesów o wykroczenia zagrożone karami z par. 279-305, 327, 343, 467 i 522 kodeksu karnego ${ }^{81}$. Co

77 Praktykę w tym zakresie można poznać m.in. z listu Oswalda Balzera do Stanisława Kutrzeby z 1907 r., zob. Listy Oswalda Balzera i Stanistawa Kutrzeby z 1907 roku, s. $171-172$.

${ }^{78}$ Może o tym świadczyć choćby sygnalizowane przez Balzera dążenie do uzyskania stałych funduszy w Wydziale Krajowym na diety wypłacane pracownikom archiwum odbywającym podróże służbowe na prowincję, tamże, s. 172.

79 Stanisław Kutrzeba jako przykład takiej sytuacji podaje w liście do Prezydium c.k. Sądu Krajowego Wyższego w Krakowie c.k. Sąd Powiatowy w Łańcucie, tamże, s. 174.

${ }^{80}$ Zob. wyżej w tekście i przyp. 60. Wytyczne Grona c.k. Konserwatorów Galicji Zachodniej zob. Listy Oswalda Balzera i Stanistawa Kutrzeby z 1907 roku, s. 173-174.

${ }^{81}$ Były to m.in. kary za zbiegowiska i opór wobec władzy, powoływanie tajnych towarzystw, lżenie, wyszydzanie, przekręcanie zarządzeń i rozstrzygnięć władzy, namawianie do bezzasadnych zażaleń na rozstrzygnięcia władzy, wystąpienia przeciwko innym narodowościom (ale też klasom, stanom prawnym, korporacjom). Określały wymiar kary za popularyzację idei „sekt religijnych” zakazanych przez rząd, publiczne znieważanie małżeństwa, rodziny, własności lub zachwalania czynności nieprawych 


\section{Robert Degen}

do spraw karnych trybunałów I instancji grono sugerowało porozumieć się z nadprokuraturą państwa, w całości zaś zachować materiały sądu górniczego w Krakowie. Jedyną uwagą dotyczącą kwestii technicznych była sugestia, aby sądy powiatowe, które nie wydzieliły jeszcze akt do zniszczenia, zawczasu wyodrębniły ze swoich registratur materiały spraw karnych warte zachowania.

Opierając się na wskazówkach opracowanych przez krakowskie grono, Kutrzeba wystosował dwa wnioski do Prezydium c.k. Sądu Krajowego Wyższego w Krakowie ${ }^{82}$. Poprosił, by wskazało działające wzorowo sąd powiatowy i sąd obwodowy, których akta można by zachować w całości. Poza tym apelował o wydanie przez prezydium okólnika wzywającego sądy powiatowe do wyłączania akt dotyczących paragrafów kodeksu karnego określonych przez konserwatorów oraz by nadsyłały - jak się można domyślać, bez dodatkowych wezwań archiwum krajowego - spisy innych grup dokumentacji wydzielonych do zniszczenia. Prezydium krakowskiego sądu wyższego wydało okólnik, o który prosił Kutrzeba, jednak nie zdecydowało się wskazać w nim sądów mających w całości przekazać akta do archiwum krajowego ${ }^{83}$.

Mimo że opisane wskazówki konserwatorskie zostały opracowane przez grono zachodniogalicyjskie, a wnioski Kutrzeby skierowane do krakowskiego sądu wyższego, to wykorzystywano je po 1907 r. na terytorium jurysdykcji obu galicyjskich sądów wyższych. Zresztą na wschodzie Galicji niezbyt różniły się one od dotychczasowej praktyki lwowskiego archiwum krajowego. W 1908 r., gdy c.k. Sąd Powiatowy w Horodence informował o wydzieleniu akt do zniszczenia, napisano, że wyłączył on „zbędne akta procesowe z lat 1856-1876, akty karne od 1873 do 1876 tudzież zapiski i protokoły z tych samych lat" ${ }^{\prime 4}$. W związku z niezbyt ścisłym opisem dokumentów archiwum krajowe poprosiło o dokładniejszy wykaz akt procesowych, aby na podstawie tych informacji upewnić się, czy wydzielona dokumentacja nadaje się do zniszczenia ${ }^{85}$. Podobnie skąpy opis przeznaczonych do brakowania akt przesłał do Lwowa sąd powiatowy w Złoczowie w 1909 r. W liście wskazano, że do zniszczenia zostały zakwalifikowane akta spraw procesowych $\mathrm{z}$ lat

i nieobyczajnych. Poza tym zawierały unormowania dotyczące kar za nieprawne posiadanie prasy drukarskiej, wykonywanie bez uprawnień sztuki lekarskiej lub chirurgicznej, za wykroczenia przeciw własności literackiej i artystycznej oraz za udział i udostępnianie pomieszczeń na zakazane gry hazardowe i czysto losowe. Zob. tamże, s. 173 i umieszczony pod edycją przyp. 17.

82 Wnioski zob. tamże, s. 174.

${ }^{83}$ L. Łysiak, Registratura sadu krajowego karnego w Krakowie i jej brakowanie, s. 185.

${ }^{84}$ CHAPU, AZ we Lwowie, f. 145, op. 1, sygn. 122, k. 21.

85 Tamże, k. 22. 
1867-1878, akta spraw drobiazgowych z lat 1867-1898 i akta spraw o przekroczeniu kar z lat 1867-1888 ${ }^{86}$. Bez dodatkowych konsultacji, na podstawie takiego jedynie zapisu, archiwum krajowe uznało wszystkie akta za makulaturę ${ }^{87}$. Bardziej rozbudowany opis materiałów wydzielonych do zniszczenia przygotował c.k. Sąd Okręgowy w Stanisławowie w 1909 r. W swoim wniosku podał dokładną listę materiałów do zniszczenia pochodzących z własnej registratury oraz z tamtejszego sądu powiatowego, ściśle informując przy tym o ich zawartości ${ }^{88}$. W tym samym roku o planowanym brakowaniu akt krakowskie archiwum krajowe zostało poinformowane przez c.k. Sąd Powiatowy w Myślenicach ${ }^{89}$. W obu ostatnich przypadkach - stanisławowskim i myślenickim - archiwa krajowe poprosiły o przesłanie części akt spraw procesów karnych, ukończonych po 1875 r., dotyczących m.in. par. 279-305, 327, 343, 467 i 522 kodeksu karnego oraz procesów o czary ${ }^{90}$.

Stosowanie zaleceń sformułowanych przez grono konserwatorów w $1907 \mathrm{r}$. nie oznacza, że archiwa krajowe ograniczały się tylko do korespondencyjnego konsultowania zawartości przeznaczonej do zniszczenia dokumentacji lub ewentualnej ekspertyzy nadsyłanych przez sądy akt spraw karnych. W $1911 \mathrm{r}$. w Krakowie została wydzielona do zniszczenia grupa akt procesowych wytworzonych w latach 1865-1897 przez c.k. Sąd Delegowany Miejski w Krakowie. W odczuciu krakowskich archiwistów miały one „wartość daleką od pierwszorzędnej, a nawet od drugorzędnej”, niemniej zdecydowali się oni na dokonanie pewnego ich wyboru. Zachowana próbka mogła stać się według nich potencjalnym źródłem do poznania „ekonomicznych stosunków okresu, do którego się te akta odnoszą"91.

\section{ZAKOŃCZENIE}

Do wybuchu pierwszej wojny światowej w Galicji nie zmieniły się ani zasady selekcji i brakowania akt, ani mechanizm nadzoru nad nimi ukształtowany na początku XX w. Tylko sądy i prokuratorie skarbu były zobowiązane do informowania archiwów o brakowaniu akt i umożliwiania ich pracownikom wyboru materiałów wartych wieczystego zachowania. Formułowane

\footnotetext{
86 Tamże, k. 95.

87 Tamże, k. 96.

88 CHAPU, AZ we Lwowie, f. 145, op. 1, sygn. 114, k. 63-67.

89 APK, AP w Krakowie, sygn. 25, s. 29-32.

90 Tamże oraz CHAPU, AZ we Lwowie, f. 145, op. 1, sygn. 114, k. 62.

91 APK, AP w Krakowie, sygn. 25, s. 61.
} 


\section{8}

w 1917 r. przez Michaela Mayra projekty zakładające objęcie takim mechanizmem wszystkich instytucji monarchii ${ }^{92}$ nie zostały zrealizowane do końca wojny. W odrodzonej Polsce zakaz brakowania jakiejkolwiek dokumentacji bez zgody archiwów państwowych zawarto już w 1920 r. w przepisach biurowych dla ministerstw ${ }^{93}$.

Trudno stwierdzić, na ile wprowadzenie w Polsce zakazu brakowania akt bez zgody archiwum było dziedzictwem wyłącznie austro-węgierskich rozwiązań w dziedzinie archiwalnej. W Prusach już w połowie XIX w. pracownicy archiwów państwowych mieli przeglądać spisy akt przeznaczonych do zniszczenia ${ }^{94}$. Nie ulega jednak wątpliwości, że aż do wydania przepisów o przechowywaniu oraz niszczeniu akt i ksiąg w sprawach sądowych i administracji sądowej w 1937 r. ${ }^{95}$ zarówno sądy, jak i archiwa państwowe w Krakowie i Lwowie korzystały z aktów prawnych wprowadzonych na początku XX w. W 1921 r. prezes sądu apelacyjnego we Lwowie wydał okólnik nakazujący stosowanie we wszystkich sądach apelacji przepisów m.in. z 1897 r. ${ }^{96}$ Rok później Archiwum Państwowe we Lwowie, odwołując się do tych wytycznych, przygotowywało się do wydawania zgód na brakowanie akt sądowych $^{97}$. W 1933 r. Eugeniusz Barwiński, oceniając akta sądów powiatowych/ /grodzkich przeznaczone do zniszczenia, cały czas posługiwał się procedurą wypracowaną w latach 1897-1907: nakazywał zawczasu wydzielić z registratury sądowej akta procesów politycznych i w takim nienaruszonym stanie przesłać je do ekspertyzy do Archiwum Państwowego we Lwowie ${ }^{98}$.

92 Zob. przyp. 50.

93 Zob. m.in. R. Degen, Kancelarie i archiwiści. Garść uwag na temat wptywu pracowników archiwów państwowych na mechanizmy pracy biurowej administracji $w$ Polsce po 1918 r., [w:] Dzieje biurokracji na ziemiach polskich, t. 2, red. A. Górak, D. Magier, Lublin-Siedlce 2010, s. 269-270.

94 L. Turek-Kwiatkowska, $Z$ dziejów stużby archiwalnej. Archiwa na Pomorzu Zachodnim w latach 1808-1914, Warszawa 1968, s. 108-109.

95 Dziennik Ustaw Rzeczypospolitej Polskiej, 1937, nr 42, poz. 335.

96 CHAPU, AP we Lwowie, f. 776, op. 1, sygn. 76, k. 4.

97 Tamże, sygn. 73 i 74, także sygn. 75, k. 1-7.

98 Tamże, sygn. 66, k. 4-5v, oraz sygn. 75, k. 22. 


\section{Appraisal, disposal and supervision on them in Galicia until the outbreak of the First World War}

Summary

Regulations about selecting documents for destruction existed in the Austrian Empire as early as the beginning of the nineteenth century. They were usually drafted by local authorities who from time to time ordered removal of old documents from their own registries and the registries belonging to their subordinate offices in order to find space for incoming new documents. In 1832, an imperial decree ordered general removal of unnecessary papers from registries. At the same time, it instructed to preserve any documents of historical value.

Ministries of the Empire followed the decree when they issued orders about appraisal and disposal of documents in their subordinate offices. The busiest in this respect was the Ministry of Justice. All the regulations issued by this ministry until 1897 were made without archivists' opinion or assistance, and no supervision was provided over the process of appraisal and disposal carried out by the historical archives which had been emerging since the early 1860 s.

In the mid-nineteenth century, the Austrian Federal Monuments Office (CentralCommission zur Erforschung und Erhaltung der Baudenkmale) was established in Vienna and it became the nucleus of the Austro-Hungarian heritage protection authority which also took interest in the archives. It employed heritage conservators and correspondents who worked in Galicia since 1888 and collected information about the provincial archives, drew up archive inventory and prevented document destruction. National administration and scientific libraries provided them with support.

In 1897, new regulations were issued calling for the courts of the Austro-Hungarian Empire to inform the national historical archives about their plans to destroy files. It was also then that the general local authorities in Galicia ordered all the subordinate offices to inform them about such plans by heritage conservators. In fact, only the Archives of Castle and Land Records (archiwa krajowe aktów grodzkich i ziemskich) in Cracow and Lviv were involved in the supervision of documents disposal by the entities that created them, because the vast majority of institutions planning to destroy documents at the time were courts.

Because of their financial situation, archives tried to collect information about the files selected for destruction by corresponding with courts, sometimes they asked for the files to be sent over so that the archivists could have a look at them personally, and occasionally their staff travelled to the provinces to carry out an expert appraisal of documentation. 